\title{
Study on Cause-Effect Relationship of Antenatal Maternal Emotional State with Neurodevelopmental Disorders
}

\author{
Vineetha Sreekumar, Vasanth C. Kurup \\ Department of Paediatrics Sarada Krishna Homoeopathic Medical College and Hospital, Kanniyakumari, Tamil Nadu, India \\ Email: drvineethasreekumar92@gmail.com
}

How to cite this paper: Sreekumar, V., \& Kurup, V. C. (2020). Study on Cause-Effect Relationship of Antenatal Maternal Emotional State with Neurodevelopmental Disorders. Psychology, 11, 663-678. https://doi.org/10.4236/psych.2020.115045

Received: January 23, 2020

Accepted: May 12, 2020

Published: May 15, 2020

Copyright (๑) 2020 by author(s) and Scientific Research Publishing Inc. This work is licensed under the Creative Commons Attribution International License (CC BY 4.0).

http://creativecommons.org/licenses/by/4.0/

\section{(c) (i) Open Access}

\begin{abstract}
Neuro developmental disorders (NDDs) include developmental brain dysfunction, which can manifest as neuropsychiatric problems or impaired motor function, learning, language or non-verbal communication i.e. intellectual disability, attention deficit hyperactivity disorder, communication disorders, epilepsy, emotional disorders, etc. This study wants to throw light on the fact that mother and fetus are one entity and whatever affects the mother will affect the child. The aim of the study is to find the cause-effect relationship of antenatal maternal emotional state with neurodevelopmental disorders. A sample of 60 cases was obtained with neurodevelopmental disorders (NDDs) which had a stressful antenatal maternal emotional history. Proper diagnostic tools such as Vanderbilt ADHD diagnostic parent rating scale, Screen for child anxiety related emotional disorders (SCARED), developmental screening test (DST), Vinland social maturity scale (VSMS) and basic IQ tests like draw a man test, gazelle drawing, Seguine Form Board (SFB) test, etc. were used for the specific diagnosis of each NDD. Details regarding the antenatal history were elicited such as family stressors, financial problems, interpersonal relationships and any other stressful events. Not only the stressful event/situation but also the type of response/emotions given by the mother during pregnancy period was elicited. The most common emotion causing NDDs was anxiety/worry/fear in the antenatal period and was about $41.66 \%$. In most cases there was intermingling of different emotions also. According to the study, the commonest cause for such negative emotions during pregnancy for the mother was found to be because of the problems created by the alcoholic husband and this cause was identified in almost 25 cases i.e., $41.66 \%$. Intellectual disability and ADHD were found to be the most common outcome. Homoeopathy is one of the best therapeutic modalities in promoting emotional healing and also in helping the process of holistic child development.
\end{abstract}




\section{Keywords}

Neuro Developmental Disorders (NDDs), Antenatal Maternal Emotional State, Homoeopathy

\section{Introduction}

- Neuro developmental function is a basic process needed for learning and productivity. Its dysfunction reflects disruptions of neuro anatomic structure or psychophysiologic function and places a child at-risk for developmental, cognitive, emotional, behavioural, psychosocial and adaptive challenges. Therefore, neuro developmental disorders (NDDs) include developmental brain dysfunction, which can manifest as neuropsychiatric problems or impaired motor function, learning, language or non-verbal communication i.e. intellectual disability, attention deficit hyperactivity disorder, communication disorders, epilepsy, emotional disorders, etc.

\section{Need of the study:}

- The prevalence of NDDs was found to be nearly $12 \%$ in Indian children aged 2 - 9 years. Nearly 1 in every 8 children might be suffering from at least one of the NDDs "as given in India bioscience news 2018" (Urvashi, 2018).

- Every child's development starts from the mother's womb itself. Therefore, every developmental disorder has to be considered from antenatal period.

- Today's antenatal check-ups are only focusing on the physical factors affecting the mother.

- In recent years there is no much concern over the behavioural or emotional teratogenicity and its possible effects on the offspring even though several studies have found a correlation between prenatal stress and child development.

- This study also tries to throw light on the probable risk factors so that it can be avoided and necessary measures can be taken to avoid such effects in the offspring.

- This study may motivate every system of medicine to find a therapeutic aid to treat such developmental disorders where cause lies in the emotional level.

\section{Does the environment affect CNS during fetal development?}

- Early influences, particularly those producing toxic levels of stress modify gene expression (epigenetic change) which is a result of environmental insults.

- According to Kleigman (2015), "Neuronal plasticity permits the CNS to recognize neuronal networks in response to environmental stimulation, both positive and negative. Thus experience (environment) has a direct effect on the physical and therefore functional properties of the brain (genetics)".

- According to Inderbir Singh \& Pal (1976), "Apart from this, a major part of the nervous system develops by around 4 months of gestation and therefore 
the environment of the fetal can affect the development of its nervous system as well" (p. 297).

\section{How antenatal maternal emotional states affect the offspring?}

The "prenatal environment" (the environment inside the uterus) of the developing child is important because everything experienced by the mother is experienced by the fetus as well. The hormones produced in a mother during any emotions passes through the placenta and will alter the character of the developing child's physiology.

According to Anindya Kumar Gupta, Monica Mongia, \& Ajoy Kumar Garg, (2017), "It is also said that the fetus develops a range of behavioural responses from early gestation itself and therefore the behavioural teratogenicity is very important" (p. 91-94).

Animal studies: [According to Vivette Glover, (1997)]

- The hypothalamo-pituitary adrenal (HPA) axis has been shown to be affected, showing increased responsiveness to a particular stimulus. For example, stressing the mother monkey, by exposure to unpredictable noise, resulted in the offspring having raised basal cortisol levels, and a raised adrenocorticotropin response during stress (Clarke et al, 1994). Similar findings have been obtained with rodents.

- Henry et al. (1994) have shown that prenatal stress of the mother caused an elevated corticoster one response in the offspring during exposure to a novel environment. Levels of both glucocorticoid type I and type II receptors were reduced in the hippocampus at 90 days, showing a possible mechanism for the long-lasting effects on the HPA axis.

\section{Human studies:}

- According to Vivette Glover, (1997), "Lou et al, 1994 conducted a study and examined the links between life events, or prenatal stressors, and fetal brain development. They compared the 70 most stressed with 50 controls from the sample. They found that both antenatal stress contributed significantly to a lower gestational age, lower birth weight, and smaller head circumference when corrected for birth weight. Prenatal stress also significantly worsened the scores on the neonatal neurological examination" (p-105-6).

- According to Schulz, Pearson, Neeley, et al., (2011). "Studies indicate that brain development, specifically that of the hippocampal system which is heavily involved in learning and memory, is adversely affected by prenatal stress and stress hormones during gestation, creating lasting effects on learning and memory" (p. 340).

According to Tandu-Umba et al., (2014) "It is also proposed that emotional stress or insult incites an adaptive response involving the hypothalamic pituitary-adrenal axis, with release of various immune (Interleukins 1, 6, and Tumor Necrosis Factor-alpha), hormonal (prostaglandins) and neurohormonal (corticotrophin-releasing hormone, hence cortisol and catecholamines) mediators along with heavy production of free radicals or reactive oxygen species (ROS) which will cause oxidation of essential macromolecules and DNA" (p. 361-370). 
Acoording to Lobo et al., (2010). "this in turn will result in alteration of vital cell functions along with systemic inflammatory state, causing long term effects" ( $\mathrm{p}$. 118-126)

\section{Different emotions have different hormones}

According to Vineetha Sreekumar, (2017). "Not only stress but also all the negative and positive emotions of a mother during pregnancy has some effects in the offspring. It is said so because during each emotion the hormones produced are different."

$\checkmark$ Acetylcholine is active when a person is angry which then trigger one to feel anxious or depressed and later leading to sudden outburst of tears.

$\checkmark$ Norepinephrine or noradrenalin is high at the time of panic or anxiety.

$\checkmark$ Epinephrine is increased during emotions of fear, anger, amusement.

$\checkmark$ Estrogen level is high at the time of anxiety.

$\checkmark$ Serotonin levels are decreased at the time of depression and sensitivity.

$\checkmark G A B A$ (gamma-butyric acid) becomes low when a person is anxious.

$\checkmark$ Oxytocin is called "love hormone" and so it is lowered when there is no good interpersonal relationship.

Role of Homoeopathic medicine

- According to Rajalakshmi (2016). "In Homoeopathy, holistic means treating the individual as a whole and not just the different parts. Homoeopathy looks at the root of the problem. If there is a behavioural issue the Homoeopath will first look at the circumstances that led to the behaviour. For example if the child has temper tantrums it may be due to a hypersensitivity to the environment or some internal discomfort."

- The history taking is also a very important aspect of the Homoeopathic consultation. Here the entire history including the state of the mother during pregnancy is taken. Homoeopathy helps with emotional healing.

- Homoeopathy believes in restoring homeostasis or external and internal equilibrium and harmony.

- There are a number of research studies that help to prove that Homoeopathic remedies act not just because of the placebo effect but can also help in changing gene expression and reduce genetic transmission of diseases and disorders (research studies by Marzatto et al. 2013 and Khuda Baksha AR, Santu Kumar Saha et al. 2013).

- Homoeopathic treatment during pregnancy can help in emotional healing and also in preventingintra uterine growth retardation. It can also help as a protective measure to prevent the bad effects of stress.

One research study by Prakash DJ et al. (2010) studied the protective role of Hypericum Perfolatium (Homoeopathic remedy) in stress induced behavioural and biochemical alterations in albino mice. The pure extract of Hypericum and Nanoparticles of Hypericum were used. It was found that both the extract and the nanoparticles significantly reduced stress induced behavioural and oxidative damage. The effect of Hypericum nanoparticle was more than that seen with the 
extract. The study showed significant improvement in memory and recall that was stress induced.

\section{Materials and Methods}

\subsection{Study Setting}

A sample of 60 cases was obtained from Sarada Krishna Homoeopathic Medical College, Kanniyakumari with neurodevelopmental disorders (NDDs) which had a stressful antenatal maternal emotional history.

\subsection{Selection of Samples}

A sample size of 60 cases with neurodevelopmental disorders (NDDs) which had a stressful antenatal maternal emotional history were selected using purposive sampling technique. For that every child will be screened for neurodevelopmental disorders using basic diagnostic tools and cases with stressful antenatal maternal emotional history will be selected from it through detailed case taking.

\subsection{Inclusion Criteria}

- Patients of paediatric age group between $6 \mathrm{yrs}$ and $18 \mathrm{yrs}$.

\subsection{Exclusion Criteria}

- Patients with antenatal maternal history of some other physical causes like exposure to radiation or chemicals.

\subsection{Study Design}

Observational study.

\subsection{Brief of Procedures}

Every case is subject to screening using basic diagnostic tools and those cases identified with NDDs will be sent for detailed case taking which includes the mothers's antenatal emotional aspect as well. Out of this a sample of 60 cases with neurodevelopmental disorders (NDDs) which had a stressful antenatal maternal emotional history. All details regarding the antenatal history was properly elicited such as family stressors, financial problems, interpersonal relationships and any other stressful events. Not only the stressful event/situation but also the type of response/emotions given by the mother during pregnancy period was elicited. All cases were not just diagnosed as NDDs but were specifically diagnosed using proper diagnostic tools such as Vanderbilt ADHD diagnostic parent rating scale, Screen for child anxiety related emotional disorders (SCARED), developmental screening test (DST), Vinland social maturity scale (VSMS) and basic IQ tests like draw a man test, gazelle drawing, Seguine Form Board (SFB) test etc. Apart from the antenatal history, details regarding the occupation of the parents, economic status, religion, age/sex of the affected child were also collected. Finally the data collected is analyzed properly and tabulated. 


\subsection{Data Collection}

Data is obtained from the patient, patient's mother and other bystanders through interview technique. The diagnosis is done through proper screening and assessment of the patient using proper diagnostic tools.

\subsection{Data Analysis}

Data is presented using charts and Tables 1-5.

Table 1. Age-wise stratification.

\begin{tabular}{cc}
\hline Age in years & $\begin{array}{c}\text { Total number of children with NDDs with } \\
\text { stressful antenatal emotional history }\end{array}$ \\
\hline $6-8$ & 18 \\
$9-11$ & 22 \\
$12-14$ & 13 \\
$15-17$ & 7 \\
\hline
\end{tabular}

Table 2. Types of emotions of mother in the antenatal period.

\begin{tabular}{cc}
\hline Type of emotion & No. of cases \\
\hline Depressed & 3 \\
Weeping & 5 \\
Lack Of Care & 7 \\
Worried/Anxious/Fear & 25 \\
Suppression of Emotions & 3 \\
Sad & 5 \\
Stressed & 10 \\
Unwanted Child (Attempt to Abort) & 6 \\
Helplessness & 5 \\
Grief & 1 \\
Insulted Feeling & 1 \\
Mental Shock & 2 \\
Fright & 1 \\
Loneliness & 3 \\
Unsecured feeling & 2 \\
\hline
\end{tabular}

Table 3. Specific type of NDD as an outcome of stressful antenatal emotional history.

\begin{tabular}{cc}
\hline Types of NDDs as an outcome of antenatal emotional history & No. of cases \\
\hline Intellectual Disability & 15 \\
Anxiety Disorder & 9 \\
Attention Defiant Disorder & 9 \\
Learning Disability & 7 \\
Attention Deficit Hyperactivity Disorder & 12 \\
Slow Learner & 5 \\
Oppositional Defiant Disorder & 6 \\
Disruptive Behavioural Disorder & 1 \\
Expressive Language Disorder & 1 \\
Epilepsy & 3 \\
\hline
\end{tabular}


Table 4. Distribution according to the occupation of parent.

\begin{tabular}{cc}
\hline Occupation of parent & Number of cases \\
\hline Coolie/Labourer & 19 \\
Driver & 3 \\
Fishermen & 8 \\
Workshop Worker & 6 \\
Businessmen & 6 \\
Carpenter & 2 \\
Cashewnut Factory Worker & 6 \\
Farmer & 1 \\
Teacher & 3 \\
Military & 1 \\
Working in Private Sector & 4 \\
Unemployed & 1 \\
\hline
\end{tabular}

Table 5. Distribution according to religion.

\begin{tabular}{cc}
\hline Religion & No. of cases \\
\hline Hindu & 45 \\
Muslim & 4 \\
Christian & 11 \\
\hline
\end{tabular}

\section{Results}

\section{Age-wise stratification:}

Children with NDDs who had a stressful antenatal maternal emotional history were stratified on the basis of their age into four groups such as $6-8,9-11,12$ $14,15-17.18$ (30\%) of them belonged to 6 - 8 age group, 22 (36.66\%) belonged to 9 - 11 age group, 13 (21.66\%) of them belonged to $12-14$ age group and 7 (11.66\%) of them belonged to $15-17$ age group. Prevalence of NDDs with stressful antenatal emotional history was found to be highest among the children of age 9 to 11 years.

\section{Gender difference:}

NDDs were more prevalent in the males than in the females. Out of the 60 children, 46 (77\%) were males and 14 (23\%) were females.

Different type of emotions of the mother in the antenatal period:

Out of the 60 cases 25 (41.66\%) had anxiety, worry or fear, $10(16.66 \%)$ was stressed mentally, 7 (11.66\%) had a feeling of lack of care, $6(10 \%)$ did not wanted a child \& attempted to abort, $5(8.33 \%)$ were sad, wept, had helpless feeling each, 3 (5\%) were depressed, had suppression of emotions \& felt lonely each, $2(3.33 \%)$ had a mental shock \& unsecured feeling each, $1(1.66 \%)$ had grief, insulted feeling \& a fright each. But most of the case had a mix of many types of emotions in the antenatal period. 
Specific type of NDD as an outcome of stressful antenatal emotional history:

From the 60 cases, 15 cases had intellectual disability, 12 were identified with ADHD, 9 had anxiety disorder and attention defiant disorder each, 7 of them had learning disability, 6 had oppositional defiant disorder, 5 were diagnosed as slow learners, 3 had epilepsy, and 1 had disruptive behavioural disorder and expressive language disorder each. It was found that in many cases more than one type of NDDs were identified in a single child or it can be said that most of the types of NDDs are co-morbidity of each others.

NDDs with stressful antenatal emotional history and socio-economic status:

There was a significant difference in the prevalence of NDDs with stressful antenatal emotional history between the children belonging to poor and average socio-economic status. Out of 60 cases, 29 (48.33\%) belonged to poor socio-economic status, $9(15 \%)$ cases belonged to average socio-economic status and $22(36.66 \%)$ cases belonged to good socio-economic status.

\section{Distribution according to the occupation of parent:}

Out of the 60 cases of children with NDDs, the occupation of 19 (31.66\%) of their parents were coolie, 8 (13.33\%) were fishermen, 6 (10\%) were workshop worker, businessmen, cashew nut factory worker each, $4(6.66 \%)$ of them worked in private sector, 3 (5\%) were teachers, drivers each, 2 (3.33\%) were carpenters, $1(1.66 \%)$ was a farmer and $1(1.66 \%)$ was unemployed.

\section{Distribution according to the religion:}

Out of the 60 cases with NDDs with a stressful antenatal emotional history, 45 (75\%) were Hindus, 11 (18.33\%) were Christians and 4 (6.66\%) were Muslims.

\section{Discussion}

According to this study the prevalence of NDDs with stressful antenatal emotional history was found to be highest among the children of age 9 to 11 years (Table 1, Figure 1). NDDs were more prevalent in males than in females i.e., $77 \%$ were males and $23 \%$ were females (Figure 2).

The different types of emotions of mothers in the antenatal period in the study were found to be emotional states such as anxiety/worry/fear, stress, lack of care, an attempt to abort the child from unwanted pregnancy, weeping, sad, helplessness, depressed, suppression, loneliness, mental shock, unsecured

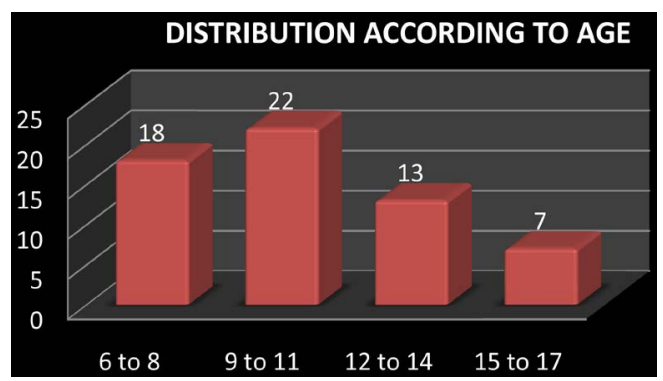

Figure 1. Age-wise stratification. 
feeling, grief, fright and unsecured feeling (Appendix). The most common emotion was anxiety/worry/fear in the antenatal period and was about $41.66 \%$ (Table 2, Figure 3). In most cases there was intermingling of different emotions also.

According to the study the most common cause for such negative emotions during pregnancy or antenatal period for the mother was found to be because of the problems created by the alcoholic husband and this cause was identified in almost 25 cases i.e., $41.66 \%$. Other causes were financial stress, problems with husband's family or mother-in-laws, death of any family members, fright/any mental shock etc (Appendix).

The outcome of a stressful antenatal emotional history were found to be as different types of NDDs such as intellectual disability, ADHD, anxiety disorder, attention defiant disorder, learning disability, oppositional defiant disorder, slow learners, epilepsy, disruptive behavioural disorder and expressive language disorder (Figure 4). In the study almost many cases had co-morbidity among themselves. Intellectual disability and ADHD was found to be the most common outcome of these (Table 3, Figure 3).

There was no much difference in the prevalence of NDDs in children belonging to poor and good socio-economic status as the percentage was $48.33 \%$ and $36.66 \%$ respectively (Figure 5). It was estimated also from identifying the occupation of parents (Table 4, Figure 6).

Majority of the children NDDs and with a stressful antenatal emotional history belonged to the Hindu religion (75\%), (18.33\%) were Christians and 6.66\% were Muslims (Table 5, Figure 7).

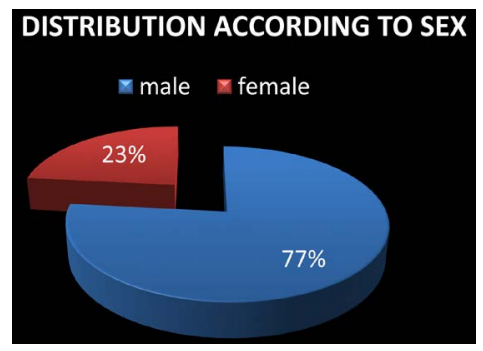

Figure 2. Distribution according to sex.

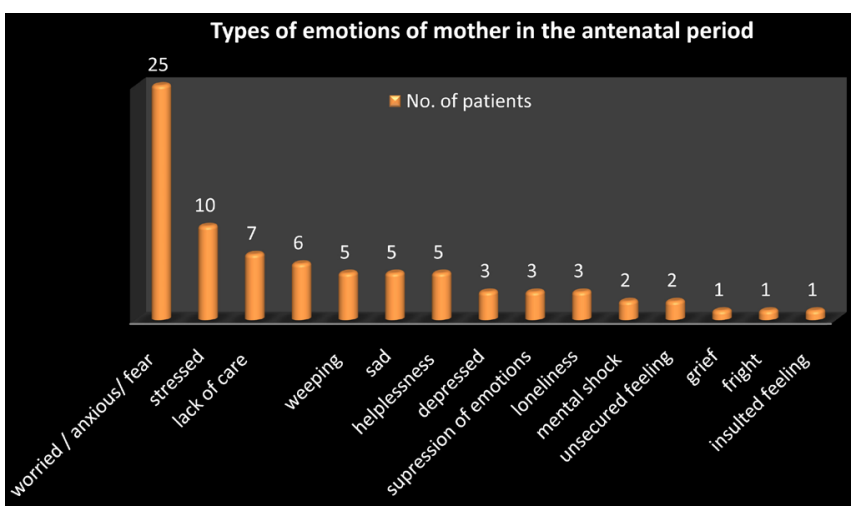

Figure 3. Types of emotions of mother in the antenatal period. 


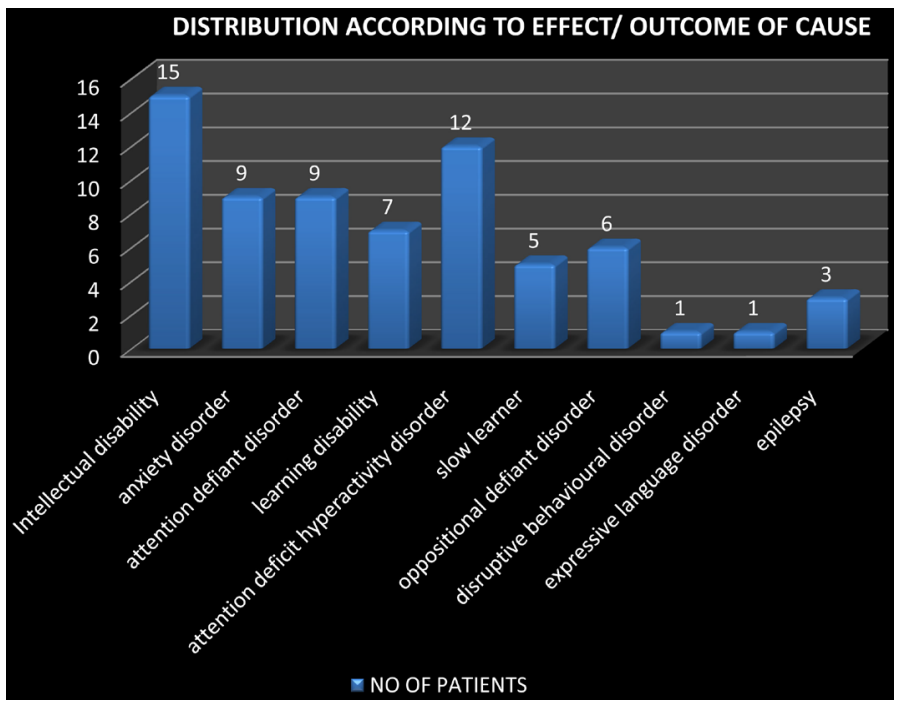

Figure 4. Distribution according to effect/outcome of cause.

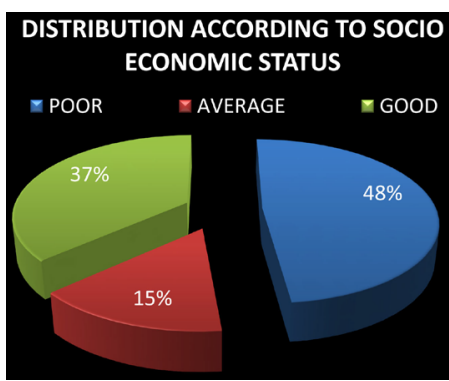

Figure 5. Distribution according to socio-economic status.

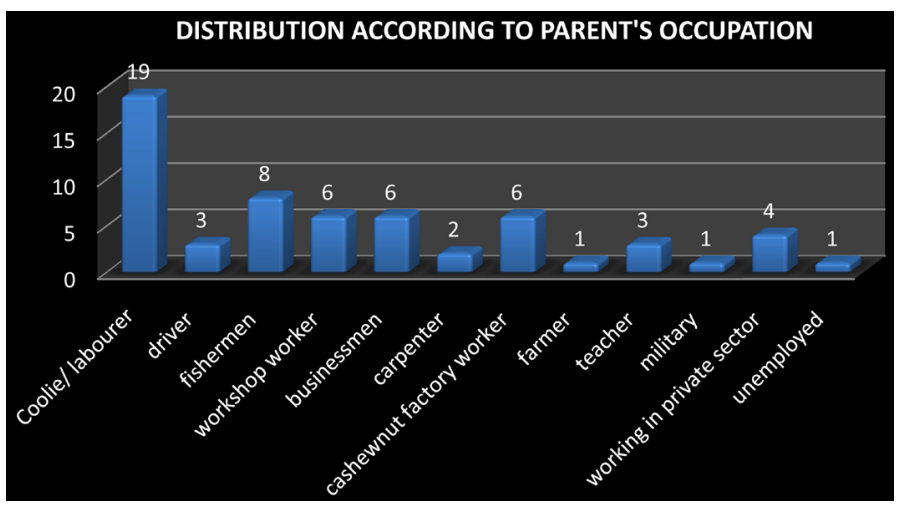

Figure 6. Distribution according to parent's occupation.

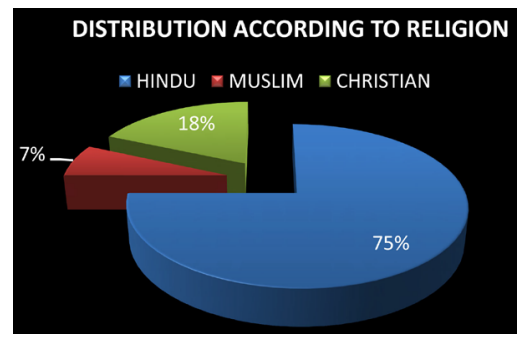

Figure 7. Distribution according to religion. 
Many research studies have proven that Homoeopathy has an emotional healing ability and also have proofs to show that it has protective ability to prevent the bad effects of stress. Also that Homoeopathy can reduce genetic transmission of diseases and disorders and help in changing gene expression.

\section{Conclusion}

The study clearly shows a strong cause-effect relationship between antenatal maternal emotional state and neurodevelopmental disorders. It is found that with different negative emotions in the mother due to different causes can create different types of NDDs such as intellectuall disability, ADHD, anxiety disorders, oppositional defiant disorder, epilepsy, attention defiant disorder, learning disability, slow learners, disruptive behavioural disorder and expressive language disorder. It was found that one of the major causes for the stress in the mother was the alcoholic husband and most of them were from poor socio-economic status.

Further studies must be done to know what exactly each emotions in the mother during pregnancy can have on the offspring and its mechanism of transmission.

This study is done to stress on the importance of antenatal period for the mother not only regarding the physical health but also in the mental sphere so that more care can be given to the mother during this period. This is to highlight that "Happy mothers have healthy children".

Homoeopathy is one of the best therapeutic modalities in promoting emotional healing and also in helping the process of holistic child development in this modern day where environment promotes a faster pace of living and where stress has become a natural component of people's lives. Homoeopathy can be a helping hand for the children who grow up with the anxiety and the emotionally stressed environment.

It is of high time that every system of medicine includes the alternative system to contribute to the ways to prevent such behavioural teratogenic effect on the offspring and also to have a therapeutic solution for such emotional causes as well in order to have a healthy generation ahead.

\section{Conflicts of Interest}

The authors declare no conflicts of interest regarding the publication of this paper.

\section{References}

Gupta, A. K., Mongia, M., \& Garg, A. K. (2017). A Descriptive Study of Behavioral Problems in School Going Children. Industrial Psychiatry Journal, 26, 91-94. https://doi.org/10.4103/ipj.ipj $39 \quad 17$

Inderbir, S., \& Pal, G. P. (1976). Human Embryology (8th ed.). New Delhi: Macmillan.

Kleigman, G.D.M., Stanton, St. Geme, Shor, Behrman (2015). Kleigman Textbook of Pae- 
diatrics. New Delhi: Elsevier.

Lobo, V. et al. (2010). Free Radicals, Antioxidants and Functional Foods: Impact on Human Health. Pharmacognosy Review, 4, 118-126. https://doi.org/10.4103/0973-7847.70902

Rajalakshmi, M. A. (2016). Homeopathy for Holistic Child Development. https://www.researchgate.net/publication/311791322

Schulz, K. M., Pearson, J. N., Neeley, E. W. et al. (2011). Maternal Stress during Pregnancy Causes Sex-Specific Alterations in Offspring Memory Performance, Social Interactions, Indices of Anxiety, and Body Mass. Physiology \& Behavior, 104, 340. https://doi.org/10.1016/j.physbeh.2011.02.021

Sreekumar, V. (2017). Happy Mothers Have Healthy Children. https://www.homeobook.com/happy-mothers-have-healthy-children-how/

Tandu-Umba, B. et al. (2014). Maternal Stress and Pregnancy Outcomes. Open Journal of Obstetrics and Gynecology, 4, 361-370. https://doi.org/10.4236/ojog.2014.47054

Urvashi, B. (2018). Neurodevelopmental Disorders in India May Affect as Many as 12\%. https://indiabioscience.org/news

Vivette, G. (1997). Maternal Stress or Anxiety in Pregnancy and Emotional Development of the Child. The British Journal of Psychiatry, 171, 105-106.

https://doi.org/10.1192/bjp.171.2.105 


\section{Appendix}

\section{Master Chart}

\begin{tabular}{|c|c|c|c|c|c|c|c|c|}
\hline $\begin{array}{l}\text { Sl. } \\
\text { No }\end{array}$ & Op No & Name & Age/Sex & $\begin{array}{l}\text { Maternal Antenatal } \\
\text { Emotional Status }\end{array}$ & Diagnosis & $\begin{array}{l}\text { Family } \\
\text { socio- } \\
\text { economic } \\
\text { status }\end{array}$ & $\begin{array}{l}\text { Occupation } \\
\text { (parents) }\end{array}$ & Religion \\
\hline 1 & $8979 / 16$ & S Aravind & $11 / \mathrm{M}$ & $\begin{array}{l}\text { Mother had fights with mother in law and } \\
\text { once had an attack of epilepsy - She was } \\
\text { depressed and used to weep daily } \\
\text { when there was conflicts in family }\end{array}$ & Moderate ID & Poor & Coolie & Hindu \\
\hline 2 & $9220 / 16$ & $\begin{array}{c}\text { R A } \\
\text { Sukunram }\end{array}$ & $10 / \mathrm{M}$ & $\begin{array}{c}\text { Mother had undergone torture from } \\
\text { husband's family. She was not provided } \\
\text { with basic food \& water ( } 1^{\text {st }} \text { trimester)-she } \\
\text { had feeling of lack of care }\end{array}$ & $\begin{array}{l}\text { Anxiety disorder } \\
\text { (social anxiety) }\end{array}$ & Average & Driver & Hindu \\
\hline 3 & $8740 / 16$ & $\begin{array}{l}\text { C Edwin } \\
\text { Sam Raj }\end{array}$ & $12 / \mathrm{M}$ & $\begin{array}{l}\text { Mother suffered from financial tension } \\
\text { and was worried }\end{array}$ & $\mathrm{ADD}$ & Poor & Fisherman & Christian \\
\hline 4 & $9482 / 16$ & Ashik & $10 / \mathrm{M}$ & $\begin{array}{l}\text { Husband was alcoholic and the mother was } \\
\text { worried that he may harm her }\end{array}$ & Moderate ID & Poor & Coolie & Hindu \\
\hline 5 & $9490 / 16$ & Mahesh & 9/M & $\begin{array}{l}\text { Mother was depressed } \\
\text { about her father's death }\end{array}$ & Moderate ID & Average & $\begin{array}{l}\text { Workshop } \\
\text { worker }\end{array}$ & Hindu \\
\hline 6 & $9700 / 16$ & A Ajay & $10 / \mathrm{M}$ & $\begin{array}{l}\text { Husband was alcoholic due to which } \\
\text { the mother had undergone stress as she } \\
\text { was not able to react in any way }\end{array}$ & Mild ID & Poor & Coolie & Hindu \\
\hline 7 & $11901 / 16$ & $\begin{array}{l}\text { M } \\
\text { Mohammed } \\
\text { Fasath }\end{array}$ & $9 / \mathrm{M}$ & $\begin{array}{l}\text { Mother was tensed and worried } \\
\text { about financial problems }\end{array}$ & $\mathrm{ADD}$ & Average & $\begin{array}{l}\text { Worker in } \\
\text { PVC } \\
\text { company }\end{array}$ & Muslim \\
\hline 8 & $11289 / 16$ & K Harish & $7 / \mathrm{M}$ & $\begin{array}{l}\text { Mother was worried } \\
\text { as her husband was an alcoholic }\end{array}$ & $\begin{array}{l}\text { Selective mutism } \\
\text { (anxiety disorder) }\end{array}$ & Poor & Fisherman & Hindu \\
\hline 9 & $11911 / 16$ & F Abisha & $15 / \mathrm{F}$ & $\begin{array}{l}\text { Husband was cheated by someone for } \\
\text { some financial issues and so mother was } \\
\text { worried and anxious about that }\end{array}$ & IDD & Poor & Coolie & Christian \\
\hline 10 & $12181 / 16$ & Ajisha & $8 / \mathrm{F}$ & $\begin{array}{l}\text { Mother was sad and was stressed } \\
\text { as her husband was an alcoholic }\end{array}$ & Epilepsy & Poor & Coolie & Hindu \\
\hline 11 & $7679 / 16$ & $\begin{array}{c}\text { V } \\
\text { Pradheesha }\end{array}$ & $13 / \mathrm{F}$ & $\begin{array}{l}\text { Mother suffered mental \& physical } \\
\text { torture(stressed) from her husband who was } \\
\text { an alcoholic and used to beat her after drinking }\end{array}$ & $\begin{array}{l}\text { Learning } \\
\text { disability }\end{array}$ & Average & Workshop & Hindu \\
\hline 12 & $7800 / 16$ & $\begin{array}{c}\text { Siva } \\
\text { Prakash }\end{array}$ & $9 / \mathrm{M}$ & $\begin{array}{l}\text { Husband used to beat her as he was an } \\
\text { alcoholic and once she had fallen down - } \\
\text { stressed and worried about the child }\end{array}$ & $\mathrm{ADHD}$ & Average & $\begin{array}{l}\text { Welding } \\
\text { (workshop) }\end{array}$ & Hindu \\
\hline 13 & $7801 / 16$ & $\begin{array}{c}\text { Siva } \\
\text { Lakshmy }\end{array}$ & $7 / \mathrm{F}$ & $\begin{array}{l}\text { Husband used to beat her as he was an alcoholic } \\
\text { even at the last trimester - was worried }\end{array}$ & ADHD & Poor & Coolie & Hindu \\
\hline 14 & $7875 / 16$ & $\begin{array}{l}\text { Adly } \\
\text { Rijoe }\end{array}$ & $8 / \mathrm{M}$ & $\begin{array}{l}\text { Husband has once beat her for some conflict } \\
\text { with mother in law and because of that } \\
\text { she had not taken food for some days - was } \\
\text { angry towards them }\end{array}$ & SLD & Poor & Fisherman & Christian \\
\hline 15 & $8104 / 16$ & Anusha & $11 / \mathrm{F}$ & $\begin{array}{l}\text { Mother was so distressed due to family } \\
\text { problems at husband's house, she came back to } \\
\text { her home and tried to abort the child as } \\
\text { she didn't like and want the child }\end{array}$ & $\begin{array}{l}\text { ADHD, } \\
\text { Mild IDD }\end{array}$ & Good & Teacher & Hindu \\
\hline
\end{tabular}




\section{Continued}

\begin{tabular}{|c|c|c|c|c|c|c|c|c|}
\hline 16 & $8383 / 16$ & R Sajin & $16 / \mathrm{M}$ & $\begin{array}{l}\text { Mother had tried to abort the child } \\
\text { at } 7^{\text {th }} \text { month of pregnancy }\end{array}$ & $\begin{array}{l}\text { ADD, } \\
\text { Borderline IDD }\end{array}$ & Poor & Fisherman & Christian \\
\hline 17 & $8253 / 16$ & $\begin{array}{c}\text { S S } \\
\text { Abilash }\end{array}$ & 9/M & $\begin{array}{l}\text { Mother was worried about the child because } \\
\text { her husband was an alcoholic \& } \\
\text { scolds her always. She was also malnourished }\end{array}$ & $\mathrm{ADD}$ & Poor & Coolie & Hindu \\
\hline 18 & $7846 / 16$ & S Sreeja & $10 / \mathrm{F}$ & $\begin{array}{l}\text { Husband used to beat her } \\
\text { after drinking alcohol worried }\end{array}$ & Mild IDD & Average & Business & Hindu \\
\hline 19 & $1012 / 16$ & $\begin{array}{l}\text { Mohammed } \\
\text { Thousif }\end{array}$ & $11 / \mathrm{M}$ & $\begin{array}{l}\text { Mother faced too much problems from } \\
\text { husband's family for not having children for } \\
\text { long even though the husband had oligospermia. } \\
\text { Still after conceiving she was always blamed } \\
\text { for every small issue. She uses to weep most } \\
\text { of the days feeling sad for blaming her. }\end{array}$ & ADD/SLD & Good & Business & Muslim \\
\hline 20 & $2594 / 16$ & Abin & $7 / \mathrm{M}$ & $\begin{array}{l}\text { Mother was not mentally ready for a baby. } \\
\text { Had uterine bleeding at 2th month } \\
\text { of pregnancy - unwanted child }\end{array}$ & ADHD/ODD & Poor & Fisherman & Christian \\
\hline 21 & $3363 / 16$ & Santhosh & $8 / \mathrm{M}$ & $\begin{array}{l}\text { Mother was beaten by her husband as } \\
\text { he was an alcoholic - stress\& lack of care }\end{array}$ & ADHD & Average & Business & Hindu \\
\hline 22 & $7843 / 16$ & V Akash & $9 / \mathrm{M}$ & $\begin{array}{l}\text { Mother was worried about her husband } \\
\text { as he was alcoholic }\end{array}$ & Mild ID & Poor & Coolie & Hindu \\
\hline 23 & $3295 / 16$ & $\begin{array}{c}\text { V } \\
\text { Vinish Raj }\end{array}$ & $11 / \mathrm{M}$ & $\begin{array}{l}\text { Mother feared her husband who } \\
\text { was an alcoholic and use to beat her }\end{array}$ & Mild ID & Poor & Driver & Hindu \\
\hline 24 & $4565 / 16$ & $\begin{array}{c}\text { S } \\
\text { Santhosh }\end{array}$ & $6 / \mathrm{M}$ & $\begin{array}{l}\text { Husband was a drunkard. Mother's basic needs } \\
\text { \& desires were not satisfied. She had to } \\
\text { go for work during pregnancy.-lack of care }\end{array}$ & Moderate ID & Poor & Coolie & Hindu \\
\hline 25 & $5826 / 16$ & S Ajith & $14 / \mathrm{M}$ & $\begin{array}{l}\text { Husband was a drunkard and } \\
\text { so the mother was worried }\end{array}$ & SLD & Average & $\begin{array}{l}\text { Cashew } \\
\text { factory } \\
\ldots \ldots+1 \ldots\end{array}$ & Hindu \\
\hline 26 & $3456 / 16$ & $\begin{array}{l}\text { Renjin } \\
\text { Karthik }\end{array}$ & $8 / \mathrm{M}$ & $\begin{array}{l}\text { During } 4^{\text {th }} \text { month of pregnancy, mother's } \\
\text { father in law suddenly got sick } \\
\text { and she was sad about that }\end{array}$ & $\begin{array}{l}\text { Expressive } \\
\text { language } \\
\text { disorder }\end{array}$ & Good & Business & Hindu \\
\hline 27 & $6189 / 16$ & Nithish & $11 / \mathrm{M}$ & $\begin{array}{l}\text { Husband was a drunkard and so } \\
\text { the mother was worried }\end{array}$ & ADHD/ODD & Poor & Coolie & Hindu \\
\hline 28 & $6320 / 16$ & $\begin{array}{c}\text { R A } \\
\text { Akash }\end{array}$ & $6 / \mathrm{M}$ & $\begin{array}{l}\text { Mother had suppression of anger from the } \\
\text { behavior of her husband as he was a drunkard }\end{array}$ & ADHD & Average & $\begin{array}{l}\text { Workshop } \\
\text { worker }\end{array}$ & Hindu \\
\hline 29 & $7828 / 16$ & Renjith & $11 / \mathrm{M}$ & $\begin{array}{l}\text { Mother had emotional stress as her husband } \\
\text { was an alcoholic and use to beat her. She was sad. }\end{array}$ & Epilepsy & Average & Carpenter & Christian \\
\hline 30 & $7829 / 16$ & $\begin{array}{c}\mathrm{R} \\
\text { Abinesh }\end{array}$ & $12 / \mathrm{M}$ & $\begin{array}{c}\text { Mother was under stress as she was helpless } \\
\text { that her husband was an } \\
\text { alcoholic and use to beat her }\end{array}$ & $\mathrm{ADD}$ & Average & $\begin{array}{l}\text { Cashew } \\
\text { nut factory }\end{array}$ & Christian \\
\hline 31 & $1264 / 16$ & $\begin{array}{l}\text { Kebin } \\
\text { Sharon }\end{array}$ & $7 / \mathrm{M}$ & $\begin{array}{l}\text { Mother had suppression of emotions as her } \\
\text { husband was an alcoholic and use to beat her }\end{array}$ & $\mathrm{LD}$ & Poor & Fishermen & Christian \\
\hline 32 & $8093 / 16$ & S Arshika & $12 / \mathrm{F}$ & $\begin{array}{l}\text { Mother was depressed as her mother died } \\
\text { when she was pregnant - grief }\end{array}$ & ODD/LD & Average & Workshop & Hindu \\
\hline 33 & $163 / 16$ & Sujin & $15 / M$ & $\begin{array}{l}\text { Husband use to beat her constantly and } \\
\text { she didn't even went to hospital for } \\
\text { regular checkups - lack of care }\end{array}$ & $\mathrm{ADHD} / \mathrm{LD}$ & Poor & Coolie & Christian \\
\hline 34 & $994 / 16$ & Sreeraj & $16 / \mathrm{M}$ & $\begin{array}{l}\text { Husband was suspicious and she was sad } \\
\text { and helpless and use to weep many days }\end{array}$ & LD & Average & $\begin{array}{l}\text { Employee } \\
\text { in cashew } \\
\text { factory }\end{array}$ & Hindu \\
\hline
\end{tabular}




\section{Continued}

\begin{tabular}{|c|c|c|c|c|c|c|c|c|}
\hline 35 & $2116 / 16$ & Vinoj & $15 / \mathrm{M}$ & $\begin{array}{l}\text { Mother was worried as her husband } \\
\text { was an alcoholic and use to beat her }\end{array}$ & LD & Poor & Coolie & Hindu \\
\hline 36 & $2586 / 16$ & Akash & $7 / \mathrm{M}$ & $\begin{array}{c}\text { Mother was mentally stressed } \\
\text { because of her husband who uses to injure her. } \\
\text { She was afraid of him }\end{array}$ & $\begin{array}{l}\text { Anxiety } \\
\text { disorder }\end{array}$ & Poor & Coolie & Hindu \\
\hline 37 & $2595 / 16$ & Vishnu & $8 / \mathrm{M}$ & $\begin{array}{l}\text { Mother was very depressed that there was } \\
\text { no one to take care of her }\end{array}$ & Mild IDD & Average & $\begin{array}{l}\text { Working } \\
\text { in a small } \\
\text { private } \\
\text { company }\end{array}$ & Hindu \\
\hline 38 & $2599 / 16$ & J Ashwin & $13 / \mathrm{M}$ & $\begin{array}{l}\text { At } 2^{\text {nd }} \text { month of pregnancy, mother had } \\
\text { tried to abort the child } \\
\text { Due to some family issues, she had an } \\
\text { insulted feeling during pregnancy }\end{array}$ & ODD & Average & Carpenter & Hindu \\
\hline 39 & $1281 / 16$ & Bavith & $11 / \mathrm{M}$ & $\begin{array}{l}\text { Mentally upset for early } \\
\text { conception - unwanted child }\end{array}$ & $\mathrm{LD}$ & Poor & $\begin{array}{l}\text { Laborer/ } \\
\text { coolie }\end{array}$ & Hindu \\
\hline 40 & $1493 / 16$ & Sajin & $12 / \mathrm{M}$ & $\begin{array}{l}\text { Mother was stressed (weeping \& not } \\
\text { reacting - emotional suppression) } \\
\text { because of the drunkard husband }\end{array}$ & SLD & Poor & Farmer & Hindu \\
\hline 41 & $1776 / 16$ & K Sindu & $15 / F$ & $\begin{array}{l}\text { Mother was } \boldsymbol{s a d} \text { that she was } \\
\text { not taken care by her husband }\end{array}$ & Moderate IDD & Poor & Coolie & Hindu \\
\hline 42 & $1233 / 17$ & S Adith & $12 / \mathrm{M}$ & $\begin{array}{l}\text { Mother had a fright on seeing a stranger } \\
\text { at } 5^{\text {th }} \text { month of pregnancy }\end{array}$ & $\begin{array}{l}\text { Anxiety } \\
\text { disorder }\end{array}$ & Poor & $\begin{array}{l}\text { Laborer/ } \\
\text { coolie }\end{array}$ & Hindu \\
\hline 43 & $1568 / 17$ & Sreerag & $6 / \mathrm{M}$ & $\begin{array}{l}\text { Mother was stressed as her husband was } \\
\text { a drunkard. She got worried when she had } \\
\text { uterine bleeding at } 5^{\text {th }} \text { month of pregnancy }\end{array}$ & ADHD/DBD & Average & $\begin{array}{l}\text { Workshop } \\
\text { employee }\end{array}$ & Hindu \\
\hline 44 & $6784 / 17$ & $\begin{array}{l}\text { S S Sobin } \\
\text { mon }\end{array}$ & $11 / \mathrm{M}$ & $\begin{array}{l}\text { At } 4^{\text {th }} \text { month of pregnancy, Mother had a } \\
\text { mental shock on knowing that her husband } \\
\text { has an extra marital relationship }\end{array}$ & $\begin{array}{l}\text { Anxiety } \\
\text { disorder }\end{array}$ & Average & Driver & Hindu \\
\hline 45 & $6949 / 17$ & $\begin{array}{l}\text { Nandana } \\
\text { Krishnan }\end{array}$ & $11 / \mathrm{F}$ & $\begin{array}{l}\text { Mother was under stress from the husband's } \\
\text { family and had a feeling that she was } \\
\text { not able to do anything (helpless) }\end{array}$ & ADHD & Average & Farmer & Hindu \\
\hline 46 & $7006 / 17$ & $\begin{array}{l}\text { Abhishek } \\
\text { R S }\end{array}$ & $13 / \mathrm{M}$ & $\begin{array}{l}\text { Husband was a drunkard and also he was staying } \\
\text { at another place during time of pregnancy. } \\
\text { She felt as if she was not cared by him }\end{array}$ & SLD & Poor & Coolie & Hindu \\
\hline 47 & $7010 / 17$ & $\begin{array}{l}\text { R S Arun } \\
\text { Krishna }\end{array}$ & $15 / \mathrm{M}$ & $\begin{array}{l}\text { Husband lost his job and mother was } \\
\text { anxious about future during pregnancy }\end{array}$ & $\begin{array}{l}\text { ADD, Anxiety } \\
\text { disorder }\end{array}$ & Poor & Unemployed & Hindu \\
\hline 48 & $397 / 17$ & Akshayath & $12 / \mathrm{M}$ & $\begin{array}{c}\text { Mother was worried as her husband was } \\
\text { an alcoholic and beat her }\end{array}$ & $\mathrm{ADD}, \mathrm{ODD}$ & Average & $\begin{array}{l}\text { Working } \\
\text { in cashew } \\
\text { factory }\end{array}$ & Hindu \\
\hline 49 & $871 / 17$ & Abinesh & $11 / \mathrm{M}$ & $\begin{array}{l}\text { Husband was a drunkard and mother felt } \\
\qquad \text { helpless and lonely }\end{array}$ & IDD, ADHD & Average & Driver & Hindu \\
\hline 50 & $6028 / 17$ & J S Ashinth & $11 / \mathrm{M}$ & $\begin{array}{c}\text { Mother was anxious about future } \\
\text { due to financial debts }\end{array}$ & ADD, ODD & Poor & Farmer & Hindu \\
\hline 51 & $9499 / 17$ & $\begin{array}{l}\text { Akena } \\
\text { Roshan }\end{array}$ & $13 / \mathrm{M}$ & $\begin{array}{c}\text { At } 4^{\text {th }} \text { month of pregnancy, was a victim } \\
\text { of a natural calamity (tsunami) and } \\
\text { mother was depressed }\end{array}$ & Moderate IDD & Poor & Fisherman & Christian \\
\hline 52 & $7845 / 16$ & $\begin{array}{c}\text { Aasima } \\
\text { Beevi }\end{array}$ & $12 / \mathrm{F}$ & $\begin{array}{l}\text { Mother had disputes with husband's family } \\
\text { \& felt sad and use to weep. } \\
\text { They live separately till then }\end{array}$ & $\begin{array}{l}\text { Moderate ID, } \\
\text { anxiety disorder } \\
\text { (selective mutism) }\end{array}$ & Good & Business & Muslim \\
\hline
\end{tabular}




\section{Continued}

\begin{tabular}{|c|c|c|c|c|c|c|c|c|}
\hline 53 & $6208 / 17$ & Vinosh & $10 / \mathrm{M}$ & $\begin{array}{l}\text { Unwanted pregnancy-mother had } \\
\text { tried to abort the child }\end{array}$ & $\begin{array}{l}\mathrm{ADHD}, \mathrm{LD} \\
\text { Anxiety disorder }\end{array}$ & Good & Teacher & Hindu \\
\hline 54 & $2948 / 18$ & Arshika & $12 / \mathrm{F}$ & $\begin{array}{l}\text { Mother was tensed \& worried since her father } \\
\text { suffered from cancer \& died next day of delivery }\end{array}$ & $\begin{array}{l}\text { Epilepsy, } \\
\text { moderate IDD, } \\
\text { Anxiety disorder }\end{array}$ & Poor & $\begin{array}{l}\text { Laborer/ } \\
\text { coolie }\end{array}$ & Hindu \\
\hline 55 & $716 / 17$ & $\begin{array}{l}\text { Nisreen } \\
\text { Farhath }\end{array}$ & $6 / \mathrm{F}$ & $\begin{array}{l}\text { At } 8^{\text {th }} \text { month of pregnancy, brother met } \\
\text { with an accident and was anxious about that }\end{array}$ & $\begin{array}{l}\text { ADD, Anxiety } \\
\text { disorder } \\
\text { (selective mutism) }\end{array}$ & Good & Business & Muslim \\
\hline 56 & $3554 / 17$ & Tharun & $6 / \mathrm{M}$ & $\begin{array}{l}\text { At } 2^{\text {nd }} \text { month of pregnancy, } \\
\text { mother saw one of her sister } \\
\text { burnt in front of her shock }\end{array}$ & $\begin{array}{l}\text { Anxiety } \\
\text { disorder }\end{array}$ & Average & Coolie & Hindu \\
\hline 57 & $3417 / 10$ & Devika & $8 / \mathrm{F}$ & $\begin{array}{l}\text { At } 1 \text { month of pregnancy, patient's father went } \\
\text { abroad \& returned back only after when the } \\
\text { patient was } 1 \text { yr of age and the mother had } \\
\text { lonely and insecure feeling }\end{array}$ & $\begin{array}{l}\text { Anxiety } \\
\text { disorder }\end{array}$ & Good & Military & Hindu \\
\hline 58 & $4198 / 13$ & $\begin{array}{c}\text { J B } \\
\text { Vrindha }\end{array}$ & $10 / \mathrm{F}$ & $\begin{array}{l}\text { Mother had financial problems and was } \\
\text { anxious about it. } \\
\text { Husband work in military and was not with } \\
\text { her during pregnancy period (felt insecured) }\end{array}$ & $\begin{array}{l}\text { Anxiety disorder } \\
\text { (social \& panic } \\
\text { anxiety) }\end{array}$ & Good & Teacher & Hindu \\
\hline 59 & $9159 / 12$ & Vijo W & $8 / \mathrm{M}$ & $\begin{array}{l}\text { Mother was at husband's home with mother in } \\
\text { law which was a new environment for her and } \\
\text { was anxious and fearful during pregnancy }\end{array}$ & $\begin{array}{l}\text { Anxiety disorder } \\
\text { (social \& } \\
\text { separation) }\end{array}$ & Average & Fisherman & Christian \\
\hline 60 & $6305 / 18$ & $\begin{array}{l}\text { Rohith } \\
\text { Krishna }\end{array}$ & $6 / \mathrm{M}$ & $\begin{array}{l}\text { Mother felt lonely as her husband } \\
\text { went abroad during pregnancy period }\end{array}$ & $\begin{array}{l}\text { Anxiety } \\
\text { disorder }\end{array}$ & Good & $\begin{array}{l}\text { Working } \\
\text { in IT } \\
\text { company }\end{array}$ & Hindu \\
\hline
\end{tabular}

